\title{
Educational Values of Madrasah PUI
}

\author{
Andewi Suhartini, Jaja Jahari, Asep Nursobah, Hasan Basri \\ Fakultas Tarbiyah dan Keguruan \\ UIN Sunan Gunung Djati Bandung \\ Bandung, Indonesia \\ andewi.suhartini@uinsgd.ac.id, djajadjahari@gmail.com, kangasnur@uinsgd.ac.id, hasanbasri@uinsgd.ac.id
}

\begin{abstract}
Religious organizations of the Union of Muslims (PUI) in Indonesia have an important influence in coloring education, especially in West Java. Proven schools and madrasah PUI spread especially from early childhood, basic, secondary and higher education. As the ultimate value of the PUI organization is the intisab (relationship binding statement) which shows believed main values relating to "God as the ultimate goal, sincere (unconditional) as a way of doing charity, always do ishlah (truth and wisdom), and love. This study focuses on the main problem about the influence of value of PUI intisab on the implementation and educational programs at the Madrasah Ibtidaiyah PUI (PUI Islamic primary education) in Ciamis. Using the survey method, the researcher examines the vision, mission, and educational goals, as well as the implementation of learning and habituation that exist in 5 MI PUI in Ciamis as a sample. The results of this study indicate that the values that exist in the intisab and ishlah ats-tsamaniyah coloring the educational values of madrasah PUI inclusively, driven by its conformity with the values of Islam universally. Based on these findings, then to apply the typical values of madrasahs need to pay attention to their conformity with the more Islamic universal values.
\end{abstract}

Keywords - intisab; madrasah; value of education

\section{INTRODUCTION}

The foundation of values is the foundation upon which the educational program stands, which illustrates the lofty ideals of an educational program. The curriculum, learning process, and educational assessment system can refer to the agreed value in the education program. What and how do PUI's values characterize PUI education?

Based on the background of the above problem, the focus of this research is the pre-eminent specialty on the implementation of madrasah education in PUI neighborhood in Ciamis. The main problem of the study in this study is the extent to which the values of the PUI's can color the education of madrasah PUI.

The basic values of the PUI are formulated in the intisab as the binding guidance of its members, which in essence is the value of the words and, by setting God as a goal in all actions. The main values as a foundation for achieving these goals include three values, namely ikhlash, ishlah and mahabbah. Working devotedly for Allah (ikhlash) as the basic value of devotion, doing various improvement efforts (ishlah) as the path taken, and strengthening affection (mahabbah) as a symbol of devotion [1].
With regard to these key values, various educational improvement efforts (ishlah al-tarbiyah) are expected to produce educational graduates who have character of ikhlash (mukhlish) people, innovators who are solutive (mukhlish), caring and affectionate to others human and natural environment (mahabbah). Ideally these values serve as a reference as a characteristic in the organization of education systems, programs, processes, and evaluations that apply to madrasahs in PUI.

\section{LITERATURE REVIEW}

Values are the main basis of education drawn from various sources, including philosophical, theological, and sociological. The strengthening of value through education is also an important issue in shaping the character of learners based on the value that is believed to be true [2]. In practice, the value base will strengthen the teacher's learning practices in order to strengthen student value [3], which affect the curriculum aspect and the learning environment reinforced by educational institutions.

Strengthening the internalization of values in education takes place primarily through teacher interaction with learners [4]. It shows that the formation of personality based on values is more influenced by the social environment and is shown in teacher behavior that reflects the values it embraces. Similarly, teacher interaction with students becomes the most important factor in internalizing values [5].

Strengthened values within PUI organizations not only cover the right to the educational aspect but also the basic values that can affect the political movement [6]. With regard to the flexibility of value owned by PUI organizations, it is possible to influence the implementation and practice of education in the PUI environment.

\section{METHOD}

This research uses the descriptive-analytic method with phenomenology approach, to obtain the meaning from various experiences of PUI madrasah in education implementation. The steps taken include the orientation stage, exploration phase, and the member check stage of the institutions of the PUI madrasah, which includes education providers and PAD madrasah residents in Ciamis district.

Determination of data sources used purposively with the beginning of determining key informant, that is PUI district 
administrator Ciamis. Selection of data sources or research subjects will take place in turn as needed to reach saturation. Although the number of research subjects is not determined, the process of rolling of this research data revolves around subjects that reside in the scope of education of madrasah PUI in Ciamis.

In addition to data sources in the form of the subject (perpetrators) PUI education, also data used data sources in the form of documents and books related to the problem of organizing education PUI in Ciamis.

The type of data used in this study is qualitative data [7]. In this study data obtained from the implementation of education madrasah PUI in Ciamis district, which includes: data on the values of the PUI-an lived by the madrasah PUI residents in Ciamis district; data on the values of the PUI-an which became the excellence of PUI madrasah graduates in Ciamis district; data on the values of the PUI-an formulated in the design of the PUI madrasah curriculum in Ciamis district; data on PUIvalues obtained by learners in the learning process in Ciamis district; and data on PUI values were applied in the process of assessing PAD's madrasah education in Ciamis district.

To obtain the necessary data in this study used observation data collection techniques, interviews, and documentation.

The data collected from interviews, field notes and documentation are processed by organizing data into categories, describing them into units, synthesizing, organizing into patterns, choosing which ones are important and which will be learned, and making conclusions so that easily understood by yourself and others. In analyzing the data, the researcher uses qualitative data analysis method. Step analysis of data used in this study includes data reduction, data presentation, and withdrawal of conclusions.

\section{RESULTS AND DISCUSSION}

\section{A. Development of PUI Madrasah in Kabupaten Ciamis}

The development of the PUI madrasah in Ciamis district is inseparable from the historical development of the PUI organization in Ciamis district and the services of its founders. PUI develops in Ciamis along with PUI in Majalengka which continues to expand to areas in eastern and northern West Java, including to the Ciamis Region. The PUI Madrasah in Ciamis marks the founding of the PUI religious organization, marked by the establishment of the Compulsory Madrasah Learning (MWB PUI) in 1944 by H. Muhammad Yusuf Siddiq located in Sarayuda village of Kertaharja village, Cijeungjing district. In its development, this MWB PUI was changed to Madrasah Ibtidaiyah MI PUI Kertaharja, although not yet formally made a regional PUI organization. Thus the education held by PUI developed earlier than the formal establishment of PUI in Ciamis, that is in 1987. This shows that the values of the PUI-a first coloring the implementation of education.

Currently, there are 29 Madrasah Ibtidaiyah (MI) in Ciamis Regency, Madrasah Tsanawiyah (MTs) of 9 madrasah, and Madrasah Aliyah (MA) is 5 madrasah. These Madrasas generally began to stand before 1987, and appear not to have been developed by formal PUI organizations, but as a manifestation of the spirit of PUI leaders who spread in Ciamis district. It also indicates that PUI-an values are more widely disseminated through education.

\section{B. Appreciation of PUI Values by the PUI Madrasah Citizens in Kab. Ciamis}

Values exist in the intisab as the foundations of the charity of PUI citizens to be the basis for the implementation of education in the Madrasahs of the PUI. The basic values upheld in the most visible educational units are embodied in the vision, mission, and goals of madrasah education. The PUI Madrasah in Ciamis develops the PUI values that exist in the intisab, visible in the madrasah vision formulation with the following characteristics.

Values exist in the intisab as the foundations of the charity of PUI citizens to be the basis for the implementation of education in the Madrasahs of the PUI. The basic values upheld in the most visible educational units are embodied in the vision, mission, and goals of madrasah education. The PUI Madrasah in Ciamis develops the PUI values that exist in the intisab, visible in the madrasah vision formulation with the following characteristics.

Values exist in the intisab as the foundations of the charity of PUI citizens to be the basis for the implementation of education in the Madrasahs of the PUI. The basic values upheld in the most visible educational units are embodied in the vision, mission, and goals of madrasah education. The PUI Madrasah in Ciamis develops the PUI values that exist in the intisab, visible in the madrasah vision formulation with the following characteristics.

- Oriented to Islamic values more universally, compared to the statement of the essence that became the basic values of PUI as an organization. Thus, the appreciation of PUI values in the management of madrasah in the vision is less likely to characterize the PUI madrasah compared with other madrasahs.

- There are differences in target of madrasah vision, namely: a) learners, b) madrasah, c) generation of Islam, and d) Islamic education.

Taking into account the two characteristics of the PUI madrasah vision formulation mentioned above, the ideals of the management of the PUI madrasah in Ciamis are more general, both in the objectives and in the values that inspire them.

The appreciation by the madrasah community toward the values that become the reference in the management of madrasah can also be seen from the formulation of madrasah mission. A Mission is "something that must be carried out or should be implemented as a translation of the vision that has been defined in a certain period of time to be a reference for the preparation of short-term, medium and long-term program." In other words, madrasah mission is an effort made madrasah in order achieve the ideals that have been established in the vision of the madrasah.

In its operations, the achievement of the mission is stated in the goal. For educational unit expressed in the purpose of education as a description of the quality level to be achieved 
within a certain period of maximum 4 (four) years by each educational unit with reference to the characteristics and/or uniqueness of each educational unit in accordance with legislation. To find out the achievement of educational goals, educational units can conduct an evaluation.

The following is presented some formulas of madrasah mission, and the purpose of madrasah education. In the mission statement illustrated efforts that will be done madrasah. In this research will be obtained a picture of whether the mission statement is possible to be implemented madrasa or not? In this case, researchers review the concepts that declared whether the concept is appropriate or not. Similarly, the conformity of the concepts that exist in the mission is really a description of the vision that has been established or not. Similarly, the relevance of the vision and mission of the madrasah with its purpose, whether to describe the achievement of mission quality or not. This suitability will ultimately represent the level of appreciation of the values expected, and whether the expected values represent the PUI's values as the characteristics and/or uniqueness of each PUI educational unit.

To get a picture of the ideals that will be realized in the future (vision) by the PUI madrasah, the likelihood of achieving these goals through the mission, and the level of achievement in the stages. Some formulation of vision, mission, and purpose of madrasa PUI in Ciamis can be seen below:

TABLE I. VISION, MISSION, AND OBJECTIVES OF MADRASAH EDUCATION 1.

\begin{tabular}{|l|l|}
\hline \multicolumn{3}{|c|}{ Vision: } \\
"The achievement of Islamic learners, achievers in scholarship, \\
skilled in working and behaving nobly in life"
\end{tabular}

In table 1 above, the madrasah mission indicates that its activities are still general, so it can not be used as a reference by the madrasah especially by education providers that is by educators and education personnel. In the curriculum has not shown a particular curriculum model, and pointed to a particular learning model that can produce graduates of achievement.

Likewise with the goal of madrasah education and its continuity with the mission of madrasah. The educational objectives of the madrasah 1 have not shown any difference between the objective formulation and the madrasah mission formula, so it does not reflect the accomplishment of the mission and has not shown the uniqueness that characterizes the vision, mission, and objectives of the madrasah.

TABLE II. Vision, Mission AND OBJECTIVES MAdRASAH EdUCATION 2.

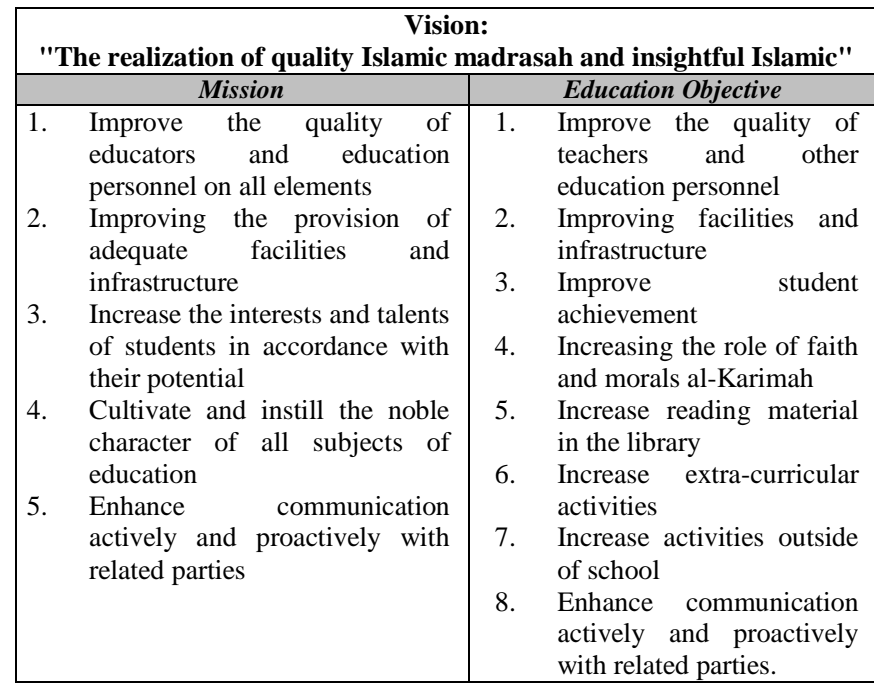

In table 2 above, some of the madrasah mission statements in madrasah 2 are more likely to be implemented to achieve the vision of the madrasah. However, when the vision statement of the madrasah is "the realization of a qualified and insightful Islamic madrasah", the sharpness of the mission becomes lessened. In this case, the vision of the madrasah does not yet have the clarity of "quality" that he aspires to. "Islamic insight" is the quality itself. Thus qualified and insightful Islamic, basically the ideals of the madrasah are qualified with the insight of Islamic.

In the mission statement "raising students' interests and talents according to their potential" is also a statement that lacks clarity of direction in the implementation of its various programs. This is because the interests and talents of students are the potential of students themselves, the most likely substantiation is to develop students' interests and talents.

From table 2 above can also be seen the purpose of madrasah education and its continuity with madrasa mission. The purpose of education in madrasah 2 is 1) to improve the quality of teachers and other education personnel, 2) to improve facilities and infrastructure, 3) improve student learning achievement, 4) increase the role of faith and morals al-Karimah, 5) improve reading material in library, 6) increased extra-curricular activities, 7) increased out-of-school activities, 8) improved communication actively and proactively with stakeholders.

From the formulation of educational objectives almost did not show the difference between the formulations of educational goals with the formulation of madrasah mission. The sentence pattern of educational goal statement still looks like a madrasah mission statement. Similarly, in terms of 
content that exist in the formulation of educational goals, has not described the purpose of education, because it is still related to the support of educational attainment goals. The purpose of improving student achievement, and increasing the role of faith and morals al-Karimah still more visible as the pattern of madrasah mission formulation.

Similarly, the formulation of educational objectives at madrasah 2 does not describe the achievers of their mission and has not shown the uniqueness of the PUI's. In this case, the PUI-an has not become a hallmark in the formulation of vision, mission, and goals of madrasah.

TABLE III. VISION, MisSION AND OBJECTIVES MADRASAH EDUCATION 3

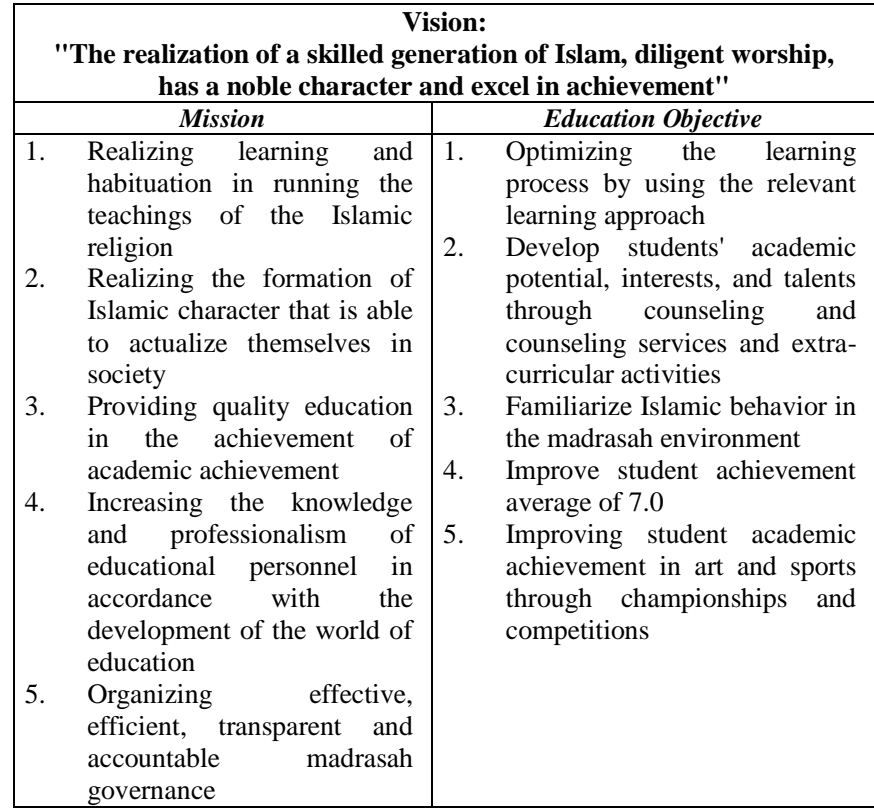

Based on table 3 above, by prioritizing some of its mission, madrasah 3 focuses on the excellence of graduates with academic achievement, and learning and habituation in running the teachings of Islam, to be able to realize the formation of Islamic character that is able to actualize themselves in society. The priority focus is supported by the increased knowledge and professionalism of education personnel in line with the development of education, and effective, efficient, transparent and accountable madrasah governance.

Similarly, the formulation of educational objectives at madrasah 3 does not reflect the accomplishment of its mission and has not shown the uniqueness of the PUI's. In this case, the PUI-an has not become a hallmark in the formulation of vision, mission, and goals of madrasah.
TABLE IV. VISION, Mission, AND OBJECTIVES OF MADRASAH EDUCATION 4

\begin{tabular}{|l|l|l|}
\hline \multicolumn{4}{|c|}{ Vision: } \\
"To realize Islamic education character of taqwa, healthy, \\
independent and skilled"
\end{tabular}

Based on table 4 above, some of the madrasah mission statements describe the efforts of madrasah citizens based on the understanding of madrasah citizens about the importance of habitual worship, and studious learning, which can be achieved through noble character.

Based on the above findings and discussions it can be drawn some basic points, namely the appreciation of the values of the PUI-an by the madrasah PUI residents in Ciamis district which seen from the vision statement, mission and objectives of the madrasah PUI has not been fully used as a reference in the implementation of education. Similarly, the vision, mission, and educational goals have not been used in the formulation as a whole as a picture of the aspirations of Madrasah citizens and the steps of achievement. The expected performance quality is also not reflected in the objectives of madrasah education.

\section{Expectations of Excellence the Ability of PUI Madrasah Graduates in Kabupaten Ciamis}

Based on the values of the PUI-an, the PUI madrasah in Ciamis district has excellence expectations, namely:

- All graduates are expected to have high fighting value, so that the knowledge obtained can be practiced both for themselves and for others, in order to seek God's willingness, and to keep the good name of themselves, teachers and institutions

- Based on the meanings that exist in the intisab I hope the graduates can achieve excellence in some things, namely: having a noble character, having a purpose in life in the willingness of God, seriously prove the recognition and testimony to Allah SWT and have the mental readiness to always surrender

- Based on the meanings that exist in the intisab I hope the graduates can achieve excellence in some ways aqidah and action (amaliah). 
- $\quad$ Based on the meanings that exist in the intisab I hope to print graduates who excel in IMTAQ, achievement and Islamic culture.

Based on the above data the expected advantage of the PUI madrassa is graduates who have a value in fighting to do, both for themselves, and for others; do sincerely just to reach rido Allah, have a personality that has a strong aqeedah. Hope is in line with the intisab.

\section{The Values of the PUI-an in PUI Madrasah Curriculum in Kabupaten Ciamis}

PUI Madrasahs in Ciamis district, as educational implementers of the national education system, have been using curriculum set by the national government. For the peculiarities of the PUI curriculum using the intisab, which appears on the vision, mission, and goals of national education.

Based on the findings of data in the form of vision, mission, and objectives of madrasah PUI, the whole affirmed the values of Islam, faith, taqwa, and noble character. Thus in the level of the idea of PUI madrasah curriculum contains Islamic values.

In the national curriculum, philosophical foundations are used in curriculum development to determine the quality of learners that the curriculum will achieve, the sources and content of the curriculum, the learning process, the learner's position, the assessment of learning outcomes, the learner's relationships with the community and the surrounding natural environment. There is basically no educational philosophy that can be used specifically for the development of a curriculum that can produce qualified human beings.

As noted above, that in the level of ideas of the PUI madrasah curriculum includes Islamic values. Islamic values as the main reference in the PUI curriculum, while still using the curriculum structure that has been established by the government nationally.

\section{E. Integration of PUI-values in the Learning Process at the PUI Madrasah in Kabupaten Ciamis}

In Madrasah PUI in Kabupaten Ciamis, there is no specific subjects or activities about the PUI's. To teach the values of the PUI-an among them by linking the content of subjects with the values of the PUI-an. In terms of linking the PUI's values, the respondents from Madrasah 1 state: "Some exist, but most importantly every beginning of the lesson always begins with basmallah reading and is directed to sincerely seek knowledge for God." This data shows that basically PAD madrasah teachers are more important to learn the students practice first start learning by reading basmallah and intend themselves to learn with sincerity. In other words it is more important that they practice the teachings of Islam, with the intention of sincerity in all activities.

Almost in line with the respondents from madrasah 1 , the data obtained from madrasah 2 are:

"In the process of learning the teachers always try to link the learning materials with the meanings contained in the intisab because there is a link between the eight contents of the intisab with the lessons that exist in madrasah ibtidaiyah especially moral aqidah. And also the content of the intisab is in line with the vision that is in our madrasas. "

This data shows that teachers always try to relate all the subject matter with the meanings contained in the intisab because it corresponds to the lessons that exist in the madrasah, and in line with the vision of the madrasah, namely "The realization of a quality Islamic madrasah and insightful Islamic." It also appears that the PUI madrasah in Ciamis does not exclusively feature the PUI's in the formal form of religious social organization, but rather emphasizes the spirit of teaching Islamic values in an inclusive way. Similarly, the similarity of PUI soul in the intisab interpreted by the respondents on the focus of strengthening of the aqidah, therefore the subjects in the madrasah that is most compatible with the values of the PUI is an aqidah.

The same is revealed from respondents in madrasah 3 and madrasah 4, the following:

\section{Respondents at madrasah 3:}

"In the process of learning the teachers always try to link the learning materials with the meanings contained in the intisab because the macro meaning intisab can be developed into the property of all Muslims."

In this case for the teacher's own "intisab" is a motivator for himself to connect the meaning intisab with learning materials, because the meaning intisab as an integral part of the values that must be owned by Muslims.

Respondents at madrasah 4:

"In the process of learning the teachers always try to link the learning materials with the meanings contained in the intisab because in essence there are 8 main lines of improvement which one of them improvement of faith and it is in harmony with our madrasah vision."

For the respondents in madrasah 4 this intisab meaning is more important is the improvement of aqidah. The drive to link the meaning of the intisab is also because there is conformity with the vision of the madrasah, not because of the peculiarity of the PUI's values in the madrasah. The vision of madrasah 4 is "to realize Islamic education characterized taqwa, healthy, independent and skilled". The vision is in conformity with the intisab in the most general context.

The formal features of the PUI doctrine are not particularly prominent in this madrasah, for example, there is no reading of "intisab" at the flag ceremony on Monday, beginning with morning learning for PUI madrasah students, as well as in other madrasah activities.

Respondents from madrasah 2 said: sakali waktos salah sawios Pengurus Daerah PUI sumping ka sakola nuju upacara bendera dinten Senen. Saatos upacara beres anjeuna naroskeun mana pembacaan intisabna? .... Ayeuna mah pami upacara bendera dinten Senen osok aya pembacaan intisab." (" Once when one of the PUI Regional Board came to school during the flag ceremony on Monday. After the ceremony finished he asked where the reading of the intisab? ... Since the incident, if the flag ceremony on Monday there is usually a reading of the intisab "). 
For the respondents in madrasah 4 , this intisab meaning is more important is the improvement of aqidah. The drive to link the meaning of the intisab is also because there is conformity with the vision of the madrasah, not because of the peculiarity of the PUI's values in the madrasah. The vision of madrasah 4 is "to realize Based on the data about the values of the PUI-an learned learners in madrasah is to relate it to the subject matter, especially subjects aqidah morals. The values of the PUI-an are not particularly highlighted, but preferably in the context of their conformity with the teachings of Islam more generally.

In addition to the values of the PUI's that learners learn in Madrasah PUI in Ciamis through curricular activities, revealed also through extra-curricular learning. In this case, the data obtained are as follows.

Respondents from madrasah 1 stated that in extra-curricular activities the learners did not study the intisab meaning. Unlike respondents from madrasah 1, respondents from madrasah 2 stated:

"In extra-curricular activities, the learners also learn the meaning of the intisab, for example in extra-curricular scout with dasa darma in which there is continuity with good intisab from the side hablum minallah and hablum minannas it."

Statement of respondents from madrasah 2 is more emphasis that in extra-curricular scout, the contents of dasa darma have conformity with the meanings intisab. Thus in studying dasa darma, learners also learn the values of intisab.

\section{Respondents from madrasah 3 stated:}

"In extra-curricular activities, learners also learn the meanings of the intisab, for example in the extracurricular UKS in which inculcated a sense of mutual help between people and it already reflects the behavior of social improvement and the spirit of helping to help (ishlahul mujtama)."

Statement of respondents from madrasa 3 is more emphasizing the values of PUI charity in ishlahul mujtama as an important value that learners learn through extracurricular UKS in which instilled a sense of mutual help between people.

\section{Respondents from madrasah 3 stated:}

"In the extracurricular activities, the learners also learn the meaning of intisab, for example in extracurricular BTQ which in its implementation refers to the goal islahu tarbiyah (improvement of education)"

For respondent 3, there is PUI-an, islahu tarbiyah (improvement of education) in extra-curricular activities Read Quranic Book (BTQ).

Based on the data obtained from the respondents above, then the values of the PUI-an studied by learners in extracurricular activities, such as Scouts, UKS, and Read the Quran (BTQ) because it has conformity with Islamic values.

Based on the above discussion, the values of the PUI-an learned learners in the madrasah PUI, both in curricular and extra-curricular learning activities by relating it to the subject matter, without being declared as the values of the PUI's, but more preferably in the context of its conformity with Islamic values more generally.

\section{F. Implementation of PUI's Values in the Process of Assessing Education at the PUI Madrasah in Kabupaten Ciamis}

The values of the PUI-an are also applied in the educational assessment process. Most importantly the implementation is in the determination of graduation. In this case in madrasah 1, respondents stated that there is no graduation criterion related to the PUI's. In Madrasahs 2, 3, and 4 the values of the PUI's are the criteria for graduation.

The following statements of respondents from madrasah 2, 3 and 4 are respectively. Respondents from madrasah 2 stated:

"In our madrasah there are graduation criteria relating to PUI-an, for example, students who passed the MIS PUI after obtaining a minimum attitude/behavior that includes both moral values and personality."

Respondents from madrasah 3 stated:

"In our madrasah there are graduation criteria relating to PUI-an, that students are graduated from the educational unit through teacher board meeting after obtaining minimum value both in final assessment for all subjects including religious subject group and noble morals. "

\section{Respondents from madrasah 3 stated:}

"In our madrasah there are graduation criteria relating to PUI-an, for example, students are graduated from the educational unit after obtaining a minimum attitude/behavior value both for noble character and noble personality."

Based on these data the values of the PUI-an, by the respondents understood as universal values that have been believed together by the ummah of Islam, namely the sphere of attitude, especially on subjects of religious education and noble morals. Respondents from madrasah 1 stated no, then it shows the values of the PUI-an as an exclusive value, which only applies to PUI religious social organizations. Therefore, although in Madrasah respondents 1 used the same criteria in the determination of graduation by respondent 1 the criteria are not considered as a characteristic of PUI's values.

\section{CONCLUSION}

The values of the PUI-an as the values that exist in the intisab color the education of madrasah PUI inclusive, driven by its conformity with the values of Islam universally. The values of the PUI were appreciated by PUI madrasah residents in Ciamis district formulated in the vision statement, mission, and objectives of the PUI madrasah, but not yet fully illustrate PUI ideals as a result of the low understanding of madrasahs towards the importance of vision, mission, and madrasah goals. The excellence expected to be achieved by PUI madrassa graduates in Kabupaten Ciamis is a graduate who has the value of fighting in charity, either for oneself or for others; doing sincerely just to reach God's willing, having a personality that has a strong aqidah.

Integrated PUI values integrate graduation, learning and assessment criteria. 


\section{REFERENCES}

[1] Persatuan Umat Islam. AD ART Renstra PUI. pp. 21-22, 2015.

[2] J. Jindal, "Value Based Education-Need of the Day," International Journal of Emerging Research in Management \&Technology, vol. 2, no. (9), pp. 24-26, 2013.

[3] T.J. Lovat and N.D. Clement, "The pedagogical imperative of values education," Journal of Beliefs \& Values, vol. 29, no. (3), pp. 273-285, 2008 .
[4] R. Thornberg and E. Oğ uz, "Teachers' views on values education: A qualitative study in Sweden and Turkey," International Journal of Educational Research, vol. 59, pp. 49-56, 2013.

[5] L. Brady, "Teacher values and relationship: Factors in values education," Australian Journal of Teacher Education, vol. 36, no. (2), pp. 56-66, 2011.

[6] W. Hernawan and E.R. Yanti, "Politik Dalam Pemikiran Kh Abdul Halim (1887-1962): Ide Dan Gerakan," Jurnal Ushuluddin, vol. 25, no. (2), pp. 153-171, 2017.

[7] S. Suryabrata, Metode Penelitian. 9th ed., PT Raja Grafindo Persada, 1995. 